\title{
"Infiltrators" or Refugees? An Analysis of Israel's Policy Towards African Asylum-Seekers
}

\author{
Hadas Yaron*, Nurit Hashimshony-Yaffe* and John Campbell**
}

\begin{abstract}
This article adopts a genealogical approach in examining Israeli immigration policy by focusing on the situation confronting African asylum seekers who have been forced back into Egypt, detained and deported but who have not had their asylum claims properly assessed. Based on immigration policies formulated at the time of Israeli independence, whose principle objective was to secure a Jewish majority state, we argue that Israel's treatment of African asylum seekers as 'infiltrators'/economic migrants stems from an insistence on maintaining immigration as a sovereign issue formally isolated from other policy domains. Such an approach is not only in violation of Israel's commitment to the Refugee Convention, it directly contributes to policies which are ineffective and unduly harsh.
\end{abstract}

\section{INTRODUCTION}

This article examines the development of immigration/asylum policy in Israel where the state uses immigration policy intended to maintain "a secure, Jewish majority state" (Perry, 2010: 157) to deter/punish African asylum seekers entering Israel via the Sinai. We find a useful starting point in the work of Sassen who argued that, in the light of economic globalization, it is no longer sufficient "simply to assert the sovereign role of the state in immigration policy design and implementation" (2000: 66). She argued that nation-states would face growing constraints and challenges - domestically and internationally - if they continued to treat immigration as a sovereign, autonomous process and policy domain. The reason why immigration/asylum is handled as an autonomous policy domain in Israel stems from an uneasy juxtaposition and contradictory relationship between Israeli policies aimed at establishing a Jewish majority state and Israel's international legal obligations as a signatory to The Refugee Convention.

Section 1 provides an overview of Israeli immigration policies which have been used to create Israel as a Jewish-majority state and the contradictions and problems which arise from this approach. In Section 2 we outline the development of Israel's refugee sector which has increasingly challenged official decisions, through lobbying and litigation, to counter dominant social and political views about the rights of African asylum seekers. Section 3 examines the problematic role played by the Israeli Refugee Status Determination (RSD) system and Israeli asylum policies and procedures. The procedure used to assess cases of disputed nationality, discussed in Section 4, illustrates the extent to which Israel violates its international legal obligations and how unworkable

\footnotetext{
* Academic College of Tel Aviv Yaffo, Israel.
}

** School of Oriental \& African Studies, London. 
this policy is. We conclude by reflecting that in a globalizing world nation-states must adopt policies that conform to international legal norms and must pursue policies through regional/multilateral initiatives if they wish them to be effective.

\section{THE ROLE OF ISRAELI IMMIGRATION POLICY}

From its creation in 1948, Israel has articulated a moral obligation to provide a place of refuge for survivors of the Jewish Holocaust (and for contemporary Jews). It is in this light that the "basic laws" which constitute the core of Israeli immigration policy need to be understood.

Israel's "Law of Return" (1950) ${ }^{1}$ states that every Jew in the world has the right to come to Israel to settle and acquire citizenship so long as at least one grandparent is Jewish. The law was intended to provide protection and shelter to Jewish people on the basis of a shared national and religious identity; there are no procedures for bestowing citizenship on non-Jews.

The "Law of Entry" (1952) $)^{2}$ regulates the right of non-nationals who are not "oleh" to enter and reside in Israel. It defines procedures for acquiring an entry visa and sets out the basis on which non-nationals may be deported. Any Jew who comes to Israel has the right to apply for an "oleh" certificate and, under "The Nationality Law" (1952), ${ }^{3}$ may become an Israeli citizen. This law allows returning Jews to acquire nationality by return, residence, birth and naturalization. The third section of this law exempts Palestinians from acquiring nationality.

In 1954 Israel adopted the "Prevention of Infiltration Law", the rationale for which was set out by Moshe Dayan, who argued that

No state is as vulnerable as Israel in the configuration of its frontiers; none has such memories of recent aggression; none is beset by the nerve-racking experience of hearing the renewal of aggression repeatedly threatened; none is assailed even now by every form of hostility short of regular warfare... (Moshe Dayan, 1955: 256-257)

Based on this frontier mentality, "The Prevention of Infiltration Law"4 defined an "infiltrator" (mistanen, Hebrew) as someone who "entered Israel knowingly and unlawfully" and who was "a national or citizen of the Lebanon, Egypt, Syria, Saudi Arabia, Trans-Jordan, or the Yemen" or who was a resident, visitor or citizen of Palestine who was armed and who sought "to cause death or serious injury to a person". "Infiltrators" were nationals of an enemy country who were subject to criminal law, were tried by a military tribunal and could be imprisoned for five years.

At the same time that Israel created the "basic laws" she also acceded to The Geneva Convention (in 1951), The Refugee Convention (in 1954) and the 1967 Protocol to The Refugee Convention. ${ }^{5}$ Israel made limited "reservations" to those Conventions which means that she remains bound by international law with regard to the establishment of RSD processes and the treatment of "refugees" (for clarity we indicate in the text when domestic policy conflicts with international law). It is notable that Israel has not incorporated The Refugee Convention into domestic law, and it has not translated the Convention into Hebrew which means that officials remain ignorant of Israel's international obligations.

The "basic laws" constitute the core of Israeli immigration law and have been used to establish Israel as a Jewish majority state. They provided the legal framework for the incorporation of 900,000 Jewish immigrants (Raijman, 2010) which inadvertently included a large number of non-Jewish Russian immigrants who were granted citizenship (Lustic, 1999). Furthermore the "basic laws" and the gradual move to adopt a formal Constitution were used to justify the suspension of the rights of nonJews, e.g. Palestinians/Arabs and Africans. As Gross has remarked of this process:

$\ldots$ in current Israeli discourse, the definition of the state as Jewish (and not just democratic) may serve to justify the full denial of civic equality to all non-Jews, particularly the denial of their 
collective rights as a national minority within Israel. It may also provide a rationale for the curtailment of democracy, especially concerning equality for Israel's Palestinian citizens' (Gross, 2004: $10)$.

Israeli law justified the alienation of Arab lands (Richmond, 1993-1994) and has contributed directly to a shortage of Palestinian labour which led business leaders to lobby government to allow employers to recruit labour from overseas. The government subsequently allowed several hundred thousand unskilled migrants from Romania, Thailand and The Philippines in to replace Palestinian workers (Bartram, 1998, Raijman, 2010).

During the 1990s the principal "immigration" issues were: (a) the arrival of 14,000 to 20,000 West Africans who overstayed their tourist/pilgrim visas (Sabar, 2010: 49); (b) the presence of 100,000 foreign workers recruited to replace Palestinian labour, most of whom entered without a visa and/or overstayed their visa; and (c) an estimated 50,000 tourists who over stayed their visas (Bartram, 1998: 315-316). Because the Government failed to monitor and manage the entry of foreigners, a decision was taken in 2001 to embark on a massive operation to deport over stayers; by the end of 2005 and at a cost of US\$100 million, Israel 'distanced' approximately 140,000 persons (Korczyn, 2011).

Rather than set out a clear policy, the Israeli government took a series of ad hoc decisions on immigration issues: (a) to accept a small number of Vietnamese refugees in 1977 and 1979 (Phillips, 2011: 10); (b) to accept one hundred Bosnian refugees in 1992 (Ben-Dor, 2008); (c) to rescue 'Ethiopian Jews' in the 1980s and 1990s (this continues under the rubric of 'family reunification'; Offer 2004); (d) to accept a group of Kosovar Albanians in 1999; and (e) to accept South Lebanese soldiers who collaborated with the Israeli Defence Force (IDF) (Herzog, 2009). To date, Israeli decisions regarding asylum - a policy arena which remains undifferentiated from immigration have sought to prevent the entry of individuals who threaten Jewish identity and the Jewish character of the state. ${ }^{6}$ Indeed Paz notes that asylum issues have been closely linked with Israeli security concerns because of the fear that the recognition of African refugees "will open up the Pandora's Box of Palestinian refugees' claims for territory, compensation and the right of return" (2011: 9).

From the early 1950s until 2001 UNHCR undertook responsibility to register and assess all asylum applications made in Israel; its recommendations were sent to Israeli officials for a final decision. The process granted refugee status to a small number of applicants all of whom were required to resettle in a third country (Table 1$){ }^{7}$

In 2002, and in response to a hunger strike by refugees who had petitioned the Supreme Court, Israel issued an asylum policy requiring UNHCR to register and process asylum applications; UNHCR's recommendations were sent to an Israeli inter-ministerial committee known as the National Status Granting Body (NSGB) for a decision (Ben Dor and Edut, 2003). Applicants were issued a UNHCR protection letter and, in most cases, a work permit (a B-1visa). Individuals whose applications were approved by the NSGB were entitled to receive a temporary residence identity card; they were not granted permanent status of any kind. Individuals categorized as citizens of 'enemy states' - which was extended to include The Sudan - were excluded from the asylum process altogether. Between 2002 and 2005 Israel had only granted refugee status to 170 individuals. ${ }^{8}$

TABLE 1

APPLICATIONS FOR ASYLUM BY DECADE/YEAR

\begin{tabular}{|c|cccccccc|}
\hline 1970s & 1980s & 1990s & 2000 & 2001 & 2002 & 2003 & 2004 & 2005 \\
\hline 95 & 236 & 755 & 6,148 & 456 & 355 & n/a & 922 & 939 \\
\hline
\end{tabular}




\section{ISRAEL'S REFUGEE SECTOR AND ITS ENGAGEMENT WITH THE STATE}

The key values underpinning associational life among Jews was Zionism and a belief in the struggle to create the state of Israel, which partly explains why human rights organizations like The Association for Civil Rights in Israel ${ }^{9}$ (established in 1972) came into being so late.

In the 1980s there was a massive growth in the number of non-governmental organizations (Gidron et al., 1998; Ben-Eliezer, 1999; Yishai, 2003). However they were relatively weak and were closely aligned with the government (Yishai, 2008; Gidron et al., 2003). To the extent that migrants who arrived in the 1990s were organized, it was into separate churches (Kemp, 2000; Sabar and Shragai, 2008) or along religious/ethnic lines. Migrant community organizations provided limited assistance to members and were not assisted by civil society organizations.

The situation began to change in early 2006 when, following a crackdown on thousands of Sudanese protesting outside the UNHCR office in Cairo, Africans began to enter Israel via the Sinai. In the face of growing numbers of Africans it soon became clear that the official Israeli response namely an attempt by the IDF to police the border - was ineffective.

We note two related developments which were set in motion in 2006: a 'refugee sector' came into being alongside the development of African community-based organizations. The development of these organizations reflected the failure of the government to establish clear, consistent and publicly accountable asylum policies and clear, inclusive policies facilitating the integration of refugees.

The complete absence of basic services for asylum seekers/refugees led to the development of NGOs who sought to provide practical support and services. These NGOs provide varying levels of support - e.g. in terms of social services, legal advice, medical assistance, shelter, access to food and child care - and possess varying organizational capabilities. Their emergence ${ }^{10}$ has been constrained by the absence of funding, inexperience and the xenophobic attitude of Israelis who see Africans as a threat to the nation and/or as "labour infiltrators" (Paz, 2011: 10-12; Yishay, 2008). ${ }^{11}$ It is against this background that NGO efforts to assist asylum seekers and migrants must be assessed.

Several organizations have played a major role in challenging asylum policy via their engagement in strategic litigation against the state. Between 1999 and 2000 "Hotline for Migrant Workers" (Hamoked, Hebrew, 1998), which promotes the rights of undocumented migrant workers and refugees, has provided para-legal support to 8,000 migrants, 800 trafficked persons and large numbers of refugees held in detention (Hotline, 2009). ${ }^{12}$ Hotline has initiated hundreds of judicial reviews and legal petitions seeking the release of detained migrants and African asylum seekers and it advocates policy change.

Tel Aviv University law clinic (established in 2002) also provides legal assistance to refugees and asylum-seekers and promotes research to advance the reform of Israeli law and policy. There are only a handful of lawyers engaged in asylum/immigration litigation, most of whom are relatively inexperienced in immigration-related litigation, which partly explains why litigation seeking to prevent deportation of Africans seeking asylum has been unsuccessful.

By expanding its litigation, the nascent refugee sector has successfully challenged decisions taken by officials on the cases of individual migrants/refugees. Their work, which is also taken up in highlevel discussions between the Ministry of Interior, UNHCR and Hebrew Immigrant Aid Society, is aimed at getting Israel to adopt policies which comply with her international legal obligations. Importantly, immigration officials are increasingly subject to new forms of judicial accountability.

\section{THE PROBLEMATIC ROLE OF ISRAEL'S RSD SYSTEM}

From 2006 onwards the number of Africans seeking asylum in Israel has increased rapidly. A total of 59,634 African "infiltrators" have arrived since January 2006 (Table 2). ${ }^{13}$ The first to arrive 
TABLE 2

THE NUMBER OF AFRICAN “INFILTRATORS” BY YEAR

\begin{tabular}{|c|c|}
\hline Year & Number entering \\
\hline 2006 & 2,789 \\
\hline 2007 & 5,434 \\
\hline 2008 & 9.253 \\
\hline 2009 & 5,318 \\
\hline 2010 & 14,744 \\
\hline 2011 & 16,816 \\
\hline $\begin{array}{l}2012 \\
\text { (January-March) }\end{array}$ & 5,250 \\
\hline Total & 59,634 \\
\hline
\end{tabular}

were Sudanese Darfuri who had been pushed out of Egypt in 2006. On crossing into Israel they were not treated as individuals in need of protection but as "infiltrators", dangerous citizens of an "enemy state" who should be arrested, detained and deported ${ }^{14}$ under the 1954 "Prevention of Infiltration Law" (which contravenes Article 44 of the Geneva Convention; see Korczyn, 2011). Following legal interventions by human rights activists and UNHCR, the government released early arrivals into the custody of various Kibbutz; for those arriving later the period of detention was shortened and most were released without special reporting restrictions. ${ }^{15}$

The story of 'Omar' illustrates the contradictions at the heart of the authorities' efforts to deter/control African asylum-seekers. Omar left his village in 2003 following an attack by Sudanese soldiers in which family members died. He fled to Khartoum, where he was detained, and after his release he escaped to Egypt. He attended the demonstration at Mustafa Mahmud Square and was detained by the Egyptian authorities. On release he crossed into Israel in October 2007 after paying Bedouin smugglers. On arrival in Israel he was arbitrarily chosen as one of five hundred Darfuri's to be given a temporary residence permit. His own asylum claim was not examined and although he is a citizen of an "enemy state" (The Sudan) he was recognized on the same terms as other refugees. In 2009 he was arrested on a criminal charge and briefly detained. At the time of his arrest his identity document was confiscated. When he was finally allowed to retrieve his ID, the Ministry of Interior refused to extend its validity. Omar has sought to renew his ID but each time the authorities require him to produce additional documentation. In 2011 the Ministry informed him that he is required to undergo an identity interview and a full asylum interview.

Initially, and exceptionally, Omar was granted status in 2007 as a member of a designated group of Darfuri refugees following intervention by the Prime Minister who responded to growing public support for Darfuri "survivors of genocide". The grant of temporary residence to a group of Darfuri asylum seekers, based solely on the date of their entry into the country, contravenes Israel's obligations to put into place procedures to assess individual applications (UNHCR, 1992: Pt. II) and is deeply problematic. For instance Darfuris who entered Israel after 2007 have not been offered temporary protection. Furthermore those who "benefited" from temporary protection have had their asylum claims taken out of the RSD system, i.e. the authorities have consistently refused to assess their claims (Hotline, nd: 8-f; Kritzman-Amir, 2009). Omar's story demonstrates the capricious nature of official decisions which identify a "group" for special consideration while simultaneously treating individual members of that group in a harsh and unpredictable manner.

The second, and largest, group of Africans to arrive were Eritreans (Table 3). In 2007 the authorities made an ad hoc decision to grant temporary work permits (B1 visas) to an arbitrarily defined group of 2000 Eritreans, based solely upon the date they entered Israel, ${ }^{16}$ a decision that violates 
TABLE 3

AFRICAN “INFILTRATORS” BY NATIONALITY (DECEMBER 2010)

\begin{tabular}{|l|cccr|}
\hline & Sudan & Eritrea & Other Countries & Total \\
\hline Number & 8,256 & 19,442 & 5,575 & 33,273 \\
Per cent & $24.8 \%$ & $58.4 \%$ & $16.8 \%$ & $100 \%$ \\
\hline
\end{tabular}

Israel's obligations under The Refugee Convention. As with Darfuri asylum applicants, the authorities have refused to assess their claims (Hotline, nd: 8-f).

While the authorities were clearly unprepared for the arrival of asylum seekers in 2006, they have continued to respond by adopting ad hoc, punitive measures including the deployment of the IDF to prevent individuals from entering Israel and detaining "infiltrators" in the country. ${ }^{17}$

From 2006 onwards UNHCR has only been allowed to issue a "protection letter" which states that asylum applicants have officially registered, i.e. UNHCR cannot issue work permits. The absence of a work permit makes it difficult for individuals to survive. Indeed, in violation of Article 17 of The Refugee Convention, Africans are vulnerable to arrest and deportation for working illegally even though their asylum application has not been examined. In 2008 the government established a new asylum registration unit and transformed Ktziot prison into a detention centre for "infiltrators" (individuals are sent there to be "identified" and medically examined). In 2008 a new "Anti-Infiltration Bill" was tabled in the Knesset (Parliament) and was passed into law in early 2012; this bill replaces the 1954 "Prevention of Infiltration Law" and, in violation of Article 16 of the Refugee Convention, introduces much harsher penalties, including detention without trial for three years. ${ }^{18}$ In 2009 the authorities ramped up efforts to arrest and deport foreigners including individuals with UNHCR protection letters (in violation of UNHCR policy; 1992: Pt. II, sec. vii).

The Egyptian military has periodically shot, arrested and detained individuals attempting to cross (but has refused to police) the border, while local Bedouin kidnap, torture and ransom Africans crossing into Israel. At the same time, and under the rubric of "hot returns", the IDF attempt to prevent illegal entry by forcing individuals back across the border (without assessing their asylum claim and without assurances from the Egyptian authorities about their treatment). ${ }^{19}$ The practice of "hot returns" - which violates Article 33 of the Refugee Convention against refoulement - was challenged in the courts by Tel Aviv University Law Clinic and Hotline for Migrant Workers. ${ }^{20}$ In July 2011 their petition was denied because the state attorney said that "hot returns" no longer occurred even though there is clear evidence to the contrary. ${ }^{21}$

Infiltrators detained at Ktziot Prison, which houses thousands of individuals, ${ }^{22}$ are held indefinitely only to be arbitrarily released without having their asylum claim taken or assessed. Individuals are given a bus ticket to Tel Aviv where they sleep rough and attempt to find work. Although the government does not publish figures on the detention of infiltrators ${ }^{23}$ its intentions are clear: in 2010 Israel began construction of a new fence on the Egyptian border, created electronic border surveillance and built a large purpose-built facility to detain up to 30,000 African "infiltrators". ${ }^{24}$ The Prime Minister's rational for these measures reflect his desire "to secure Israel's Jewish and democratic character". 25

The state has also attempted to restrict the right of movement of asylum seekers to specified areas (the so called "north to Hadera, south to Gedera" policy) in an effort to make Tel Aviv a "no go area" for cheap "infiltrator labour" (Paz, 2011: 6-7). This decision - which violates Art. 26 of the Refugee Convention - prevented asylum seekers from accessing legal advice and assistance from NGOs. Infiltrators caught in Tel Aviv were detained. In response to a court case ${ }^{26}$ in mid2009 the Ministry withdrew this policy. 
In contrast to UNHCR protection letters, "conditional release" visas valid for three months were issued by the authorities in 2007 to Eritreans and Sudanese and appear to have provided some protection against arrest and deportation. These visas were issued by the Ministry of Interior in accord with Israel's "Law of Entry". After Israel assumed ownership of the RSD system, asylum applicants were issued with "conditional release" visas while they waited for their claim to be assessed. From 2010 onwards the visa bears a stamp which says: "This visa is not a working permit". The language on the permit sends a clear message to prospective employers that hiring visa holders is not "legal". Following successful litigation which led the Israeli Supreme Court to find that Israeli's who employ visa-holders would not be fined, the Prime Minister announced "a crackdown" on infiltrators (whom he termed "migrant workers") and stated that "Employers who hire illegal immigrants can expect to start paying significantly higher fines as part of a government campaign against illegal immigration". ${ }^{27}$ In fact individuals holding this visa are discriminated against and struggle to find work; their ambiguous legal status means that they are unable to establish themselves and their families. Asylum applicants live in a state of constant insecurity in crowded conditions; they rely on irregular and low paid work and the support of friends, relatives and NGOs.

The authorities have sought to establish "return" agreements allowing Israel to deport individuals to their country of origin without assessing their asylum application (which violates Article 33 of the Refugee Convention). For example, Ministry of Interior officials recently met with representatives of the Eritrean government who rejected an agreement ${ }^{28}$ to return their nationals. Indeed, despite clear evidence to the contrary, the Eritrean ambassador stated that its nationals in Israel "are not refugees, but work migrants" whose forcible return will "undermine national morale and [they will] bring back with them frustration and bitterness". ${ }^{29}$

The Ministry has established an unpublished agreement with Ethiopia which allows officials to document individuals held in immigration detention and deport them without assessing their asylum claim. Various sources including UNHCR have confirmed to the authors that among those deported were: (a) "Ethiopians of Eritrean Decent" (i.e. "mixed nationals" who are stateless and at risk of possible persecution in Ethiopia, see Campbell, 2011), (b) nationals of Eritrea, and (c) individuals from other African countries. Deportees are placed into refugee camps in Ethiopia; worryingly, neither the Israeli authorities nor UNHCR know what happens to them. ${ }^{30}$

Critically the vast majority of asylum claims are not assessed; this includes Darfuris and Eritreans who were given temporary status as members of a specific "group" (Hotline, nd: 8-f). Legal petitions have forced the Ministry of Interior to reveal that in 2008-2009 only three individuals out of the 3000 cases it reviewed were granted asylum and that during 2010-2011 the government approved one claim while rejecting 3,692 other claims ${ }^{31}$ In cases where UNHCR made a positive recommendation, the NSGB set the recommendation aside without explanation. ${ }^{32}$ The Ministry does not publish its decisions. Furthermore it refuses to provide reasons why individual asylum claims are rejected and it refuses to reveal the criteria used to determine the identity of Africans held at the registration unit. Crucially an appeal process independent of the Government has not been established. ${ }^{33}$

Officials believe that the creation of 'group protection' for Darfuri's and Eritreans has contributed to "nationality swapping" (when individuals falsely register as Darfuri or Eritrean) and have responded by initiating new procedures to 'identify' individuals. In mid-2011 an increasing number of Eritrean claims were rejected despite a 2011 statement from UNHCR that most Eritreans have a valid claim for asylum.

Unsurprisingly the capricious nature of official decisions and constantly changing policies create considerable anxiety and insecurity among asylum seekers, as the case of Hassan illustrates.

Hassan was among those Eritreans issued a B-1 visa. He has been a refugee from early childhood when his family fled from Eritrea into Sudan in the 1980s. After Eritrean independence in 1993 his family returned to Eritrea but got caught up in the border conflict with Ethiopia in 1998. 
Hassan, then a child, was conscripted into the military but escaped to a refugee camp in Sudan. In Sudan he was not granted status and, afraid of being arrested, he fled to Egypt and then to Israel. Since Hassan has lived most of his life outside Eritrea and his Eritrean documents were issued in Sudan, the registration unit concluded that he was an Eritrean and confiscated his visa until, months later, legal intervention forced the authorities to return it.

Others less fortunate than Hassan are detained and deported before they are able to appeal (Hotline, nd: sec. 4.1-4.2). His case underlines the insecurity which arises from the failure to assess individual asylum claims and from constant policy changes. The government's recent announcement that it would build a new, purpose-built detention facility for "infiltrators" and that the visa issued to some asylum applicants was "not a work permit" seem designed to make asylum seekers panic.

In 2010, UNHCR transferred responsibility for the entire RSD process to a newly created RSD Unit in the Ministry of Interior ${ }^{34}$ and in January 2011 a new "Procedure for Handling Political Asylum Seekers in Israel”"35 was issued. The document states that “... persons staying illegally, who have submitted an application for political asylum, will not be deported until a final decision is made regarding their application".

The new procedure stipulates that: (a) applications are to be submitted to the Ministry which registers and "identifies" applicants using a preliminary interview; (b) should any suspicions about a claim arise, a "basic interview" should follow; (c) if the Ministry dismisses an application, the applicant has a right to appeal; (d) applications deemed problematic may be subject to a further comprehensive interview (a decision on which can be referred to an Advisory Committee); (f) the Chair of the Advisory Committee can consider an application and dismiss the claim (a decision on the case is referred to a "Plenum" who send their recommendation to the Interior Minister); (g) The Minister considers the recommendation and may recognize the applicant as a refugee or deport the person; (f) applicants are supposed to be notified of the decision in writing within 14 days; (g) an individual can appeal against a Committee decision; (g) individuals who are "subjects of enemy or hostile states" will not be granted permits to stay; (h) if recognized, a person will be issued a temporary "licence" to remain for up to three years; and (i) the procedure through which a recognized refugee can apply to bring their spouse and minor children to Israel is outlined.

While an applicant is allowed to bring a lawyer to the interview, in fact there are very few refugee lawyers and asylum applicants cannot afford them. Furthermore while in theory it is possible to appeal against a decision, it is not clear on what basis decisions are taken or on what grounds an appeal might be made (Hotline, nd). The document is premised on the assumption that claims will lack credibility or will otherwise fail to meet the criteria set out in the Refugee Convention (which has not been incorporated into domestic law and is not enforceable in domestic courts).

Three additional points are worth noting. First, Darfuris and Eritreans who were given temporary work permits in 2007 have had their asylum applications removed from the RSD process despite the fact that the very rationale for granting them protected status strongly suggests that their claims should succeed. Second, in violation of Article 24, Sec. C and Article 8 of the Refugee Convention respectively, asylum applicants are not entitled to work, to social security/benefits or to non-emergency medical care. Finally, individuals found to have valid claims are only provided with temporary "licences" to stay in the country.

Recently the registration Unit, which uses the new procedure, has called asylum applicants for an interview to renew their permit (which is required every three months). But when asylum applicants attend for an interview they are arrested and detained without being given a right of appeal. In response "Hotline" and The Association for Civil Rights filed a petition in the administrative courts arguing that the arrests undermined the principle of non-refoulement in Article 33 of The Convention. 36

The RSD process, now entirely in the hands of officials, is deeply flawed and in many respects contravenes international law; furthermore RSD does not provide a fair assessment of asylum claims and Israel policies generally are ineffective in stemming the flow of "infiltrators" into the 
country. Rather than carefully designing and implementing policies which conform with Israel's international legal obligations, the authorities rely on poorly thought out ad hoc decisions which, when challenged in the courts, lead to equally unlawful and ineffective decisions.

\section{PROCEDURES TO ASSESS THE DISPUTED NATIONALITY OF DETAINED ASYLUM SEEKERS}

A telling example illustrating the flawed and unlawful nature of Israeli procedures arises from the manner it assesses the nationality of the 250-plus individuals currently held in detention. About 150 are these individuals are thought to be "mixed Ethiopian-Eritrean nationals" 37 or Ethiopians of Eritrean Descent who, in all probability, are de jure stateless persons (Campbell, 2011). In response to a ACRI legal petition the Ministry published the three-page procedure ${ }^{38}$ it uses to identify disputed nationals. The procedure requires "aliens" to provide documents - i.e. passports, birth certificates, ID etc issued by another country which would "prove" their nationality - and/or a signed request from an embassy that the person is obtaining documents, a travel document etc. and/or that it will provide data to confirm the person's identity. Detainees are also told to provide the names and addresses of family who can confirm their nationality.

When officials receive the required information they are supposed to contact foreign consulates "to check if the alien may be deported". The Ministry must come to a decision within sixty days after which a disputed national should be released from detention. If it proves impossible to deport a person within one year of their incarceration, applicants can request a temporary visa (a " $B / 1$ waiver") for six months which may be renewed for a further six months. Their case is supposed to be reviewed one year after their release. The problematic nature of this procedure becomes evident when we look at individual cases.

Yohannes was born in Addis Ababa, Ethiopia in 1987; his parents were both born in Eritrea but had migrated to Ethiopia. After his father's death his mother married an Ethiopian national who "adopted" Yohannes and his elder brother. During the 1998-2000 border war with Eritrea, his adoptive father intervened to prevent them from being deported as "alien" Eritreans even though neither boy had ever been issued with Eritrean (or Ethiopian) identity papers. After his mother's death in 2003 their "father" forced both boys out of the house; during the 2005 Ethiopian election his brother was killed and Yohannes was arrested and detained. On release he fled the country, travelling through East Africa for five years before entering Israel in 2010. In his interview at Lod it was accepted that: he was born and raised in Ethiopia; he was an ethnic Eritrean; he spoke Amharic and Tigrinya; and he had never been to Eritrea. He was asked what his nationality was, to which he replied 'Eritrean'. On the basis of this reply the Ministry decided that he was being uncooperative and detained him indefinitely. Officials reasoned that "it is hard to believe how he and his family managed to live, work, study and own property in Adis without papers from Ethiopia... The subject failed to prove having any common knowledge about Eritrea, answered most questions wrong ... To sum up I identify the subject to be an Ethiopian citizen, and since he continues to claim the contrary, his case is rejected". He was released from detention in early 2011 only to be detained again in July 2011 when he came to renew his visa.

The information Yohannes ${ }^{39}$ supplied to the authorities should have established him as a stateless person who cannot be returned to Ethiopia or Eritrea and he should have been released and given status. His re-arrest and detention in July 2011 when he went to renew his visa underlines the arbitrary and unlawful way which officials use the procedure.

There are, however, other problems with the procedure. First immigration-detention officials are often "unaware" of the procedure and fail to inform detainees about it. Second, the requirement that detainees provide documentation contravenes UNHCR guidance which states that "the mere 
possession of a valid national passport is no bar to refugee status" (1992: 48). Furthermore when Eritreans ask family to send documents, the package cannot be opened by the detainee without invalidating the documents. In some cases a photograph is sent of the entire family - holding key documents which were mailed to the detainee - in front of a clearly identifiable location in Eritrea.

The authorities either reject this evidence or hold on to it without assessing the claim. ${ }^{40}$ Finally, mixed Ethiopian-Eritrean nationals are understandably reluctant to approach the Ethiopian embassy because Ethiopia denationalized its ethnic Eritrean nationals, and because Ethiopian and Eritrean officials refuse to recognize such persons as nationals (Campbell, 2011).

The procedure ensures that Ethiopians/"mixed nationals", Eritreans, Ivorians, Sudanese and many others who may well have a claim as a stateless person have no prospect of being "identified" and released (instead they are "distanced" using the unpublished agreement with Ethiopia). Finally it should be noted that individuals are detained even when the Ministry's decision is overturned in court.

\section{CONCLUSION}

Immigration policies in Israel, as elsewhere in Europe and around the Mediterranean, have failed to grasp the nature and impact of globalization reflected in the expansion in the number and movement of migrants and refugees transiting the world (a process linked directly to neo-liberal economic policies).

In an attempt to circumvent growing immigration and border controls, migrants and individuals fleeing persecution are undertaking longer overland routes on which they spend longer periods of time in transit and where they are increasingly subject to greater danger, as evidenced by their treatment in Libya, Morocco (Hamood, 2006; Collyer, 2006) and Israel. Officials fail to ask why the creation of growing border/immigration controls are ineffective in stemming this movement? The reason why such policies fail is that governments refuse to acknowledge a key factor driving the process, namely the demand for cheap migrant labour (de Hass, 2008). Instead officials adopt an "apocalyptic" approach and blame refugees and migrants for recurring social and political problems which are used by right-wing politicians to create public discontent and fuel racism.

It is in this context that the presence of the migrant/refugee brings into sharp relief the limitations and failures of unilateral approaches to immigration/asylum policy just as it underlines the need for multilateral policy initiatives. Israel's failure to incorporate the Refugee Convention into domestic law appears to have arisen from an over-riding political concern to ensure that Israel remains a Jewish state. That nationalist vision has become linked to a major policy failure, namely a refusal to de-link immigration policies from ad hoc asylum policy decisions which violate the country's international legal commitments.

The arrival of 60,000 African asylum seekers has brought into sharp relief Israel's refusal to develop a coherent asylum policy and its failure to comply with international law, as evidenced by official reliance on a series of ad hoc decisions - e.g. grants of protection for arbitrarily defined groups of asylum seekers, constant changes to 'policy' and procedures, reliance on deportation and detention, problems arising from a failure to develop a fair and independent RDS system etc. - result in decisions which are ineffective and are overturned in court. In this regard government statements that Africans are "infiltrators"/economic migrants represents an attempt to deflect public attention away from Israel's international legal obligations and poorly designed policies. Government statements and policies have directly contributed to growing public hostility towards black, non-Jewish 'infiltrators' and have led to anti-refugee/foreigner demonstrations, riots and assaults on Africans and organizations which support African asylum-seekers. ${ }^{41}$

In the age of globalization effective approaches to immigration/asylum policy require domestic policies which conform to international legal norms and which are pursued through regional and multilateral approaches to shared concerns about security, trade, immigration etc. If Israel fails to 
adopt and pursue such policies it will find that its efforts will be ineffective and it will face three insoluble problems. First there will be high domestic political costs with a go-it alone approach toward immigration/asylum as evidenced by growing anti-African demonstrations. Second Israel will face growing international condemnation and political isolation regarding its treatment of refugees, which will make it impossible to manage, much less stem, the flow of refugees and migrants into the country (unless officials are prepared to direct further violence at asylum seekers). Finally, Israelis will pay a high economic cost: the recent announcement of a two per cent "tax" on every government department to fund the construction of the security fence on the border, a detention centre etc is the first step in this direction. ${ }^{42}$

\section{NOTES}

1. See: http://www.jewishvirtuallibrary.org/jsource/Immigration/Text_of_Law_of_Return.html (accessed 1 June 2012)

2. See: http://www.israellawresourcecenter.org/israellaws/fulltext/entryintoisraellaw.htm. (accessed 1 June 2012)

3. "Oleh" means a Jew who returned to Israel. See: http://www.israellawresourcecenter.org/israellaws/fulltext/ nationalitylaw.htm (accessed 1 June 2012)

4. See: http://www.israellawresourcecenter.org/israellaws/fulltext/preventioninfiltrationlaw.htm

5. See: http://www.adh-geneva.ch/RULAC/international_treaties.php?id_state $=113$. (accessed 1 June 2012)

6. A common theme of the Prime Minister, see for instance: "Netanyahu: migrants threaten our national identity" (The Times of Israel, 20 May 2012).

7. Source: UNHCR Statistical Year Books. There is no data for 2003.

8. The figure was provided by UNHCR in a meeting at the Knesset in November 21st 2005, see: www.knesset.gov.il/protocols/data/rtf/pnim/2005-11-21-02.rtf (accessed 1 June 2012)

9. See: http://www.acri.org.il/en/?page_id $=158$ (accessed 1 June 2012)

10. For an overview of the refugee sector see: http://www.frlan.org/node/263. (accessed 1 June 2012)

11. See: http://www.migrant-rights.org/2010/11/14/racism-toward-african-asylum-seekers-on-the-rise-in-israel/ and 'Tel Aviv demonstration against illegal immigration' (Arutz Shiva News 22 November 2011).

12. See: http://www.hotline.org.il/english/index.htm.

13. Government statements in September 2012 regarding the effectiveness of the border fence in stopping infiltration are premature because there are many factors outside Israel's control which are more likely to affect the movement of Africans.

14. See: "Israel-Africa: deportation of Africans sparks concern" IRIN, 22 August 2007, available at: http:// www.irinnews.org/report.aspx? reportid $=73854$. $($ accessed 1 June 2012)

15. Source: Ministry of Interior reports and various Israeli press reports, Also see: 'PM: Security fence to be built along Jordanian border' (Jerusalem Post, 01/01/2012).

16. See: "The Ministry of Interior: 2000 Eritrean's Can Work if They Leave the Center of the Country" (HaAretz 5 August 2008) at http://www.haaretz.co.il/misc/1.1340925

17. Source: various Ministry of Interior reports.

18. See: "Israel passes draconian law on illegal immigrants" (The Independent, 11 January 2012) at: http:// www.independent.co.uk/news/world/middle-east/israel-passes-draconian-law-on-illegal-immigrants6287795.html. (accessed 1 June 2012)

19. See: "Egypt: Stop Killing Migrants in Sinai", Human Rights Watch September $10^{\text {th }} 2009$, available at: http://www.hrw.org/news/2009/09/10/egypt-stop-killing-migrants-sinai

20. Petition number 7302/07 served to the Supreme Court on 28 October 2007, Verdict given on 7 July 2011.

21. See: 'IDF arresting illegal aliens in Sinai' (Arutz Sheva, 10 August 2012).

22. See: 'Haaretz special report: Israeli jail grappling with rising swell of illegal African immigrants', Haaretz.com, 24 November 2011).

23. For information on the detention estate and estimates of the number of persons held in detention, see: http://www.globaldetentionproject.org/countries/middle-east/israel/introduction.html.

24. See: "Israel's cabinet proposes building new detention centre for African infiltrators" (Haaretz 26 Nov. 2010 at: http://www.haaretz.com/news/national/israel-s-cabinet-approves-building-detention center-for-african-infiltrators-1.327362. See also: "Israel's detention profile" at: http://www.globaldetentionproject.org/ countries/middle-east/israel/introduction.html (accessed 1 June 2012) 
25. See: "Israel to build surveillance fence along Egyptian border", The Guardian (1 November 2010).

26. Administrative petition 1694/08 served 16 April 2008.

27. Supreme Court petition no. 6312/10; the decision was announced on 16 January 2011; see: "Netanyahu announces crackdown on illegal migrant workers" (Haaretz.com, 6 December 2011).

28. Source: official from the Ministry of Interior, 14 July 2011.

29. See: "Eritrean ambassador: We won't take back infiltrators", 1 December 2011 at: http://www.ynetnews. com/Ext/Comp/ArticleLayout/CdaArticlePrint. Stories abound about corrupt embassy officials who compel individuals to sign a "confession" and pay in US currency for a passport or travel document which the Israeli authorities do not recognize.

30. See: "Israel using technicality to deport Eritrean asylum seekers to Ethiopia", Haaretz.com 24 October 2011); "Israel Deports Asylum Seekers to Ethiopia in Spite of Possible Danger to their Fate", Haaretz (24 October 2011).

31. Letter from Mali Davidyan to Yuval Livnat dated 12 April 2010; see also US (2011, sec. d).

32. Letter from Elinor Gezer to Yuval Livnat dated 12 July 2011.

33. Letter from Dudu Weizman to the ARDC dated 20 October 2010. Individuals are given "rejection letters" but these do not necessarily set out the basis on which a decision was made.

34. The case files handed over to the Ministry to assess contained thousands of applications including individuals who had resided in Israel for 10 years.

35. See: http://www.srlan.org/beta/index.php?option $=$ com_content\&view $=$ article\&id $=111 \% 3$ Aisrael-probono\&catid $=36 \&$ Itemid $=120($ accessed 1 June 2012)

36. Petition number 38049-05011.

37. See: "Israeli judge: The state is risking the lives of Eritrean refugees" (Haaretz.com, 21 Feb. 2012).

38. Cf. "Procedure for Handling an Alien who claims that there is no country to which he can be deported" (No. 10.1.0015, dated 7 July 2004). Copy in author's possession.

39. Source: interviews conducted by ARDC and the Ministry of Interior (copies in author's possession).

40. Source: interview with UNHCR officials on 13 July 2010 in Tel Aviv.

41. See: Y. Lappin "Tel Aviv anti-African rally ends in rioting, assaults", The Jersusalem Post (27 May 2012).

42. The cost of fencing the Sinai border and detaining a further 5,000 "infiltrators" is to be met by cutting two percent from the budget of every government office; see: "Netanyahu set to present plan to tackle illegal immigration from Africa" (7 December 2011, Haaretz.com).

\section{REFERENCES}

Bartram, D.

1998 "Foreign workers in Israel: History and theory", International Migration Review, 32(2): 303-325

Ben- Dor, A.

2008 “Asylum Seekers and Refugees-Unwanted Guests in Israel”, [in Hebrew]. http://www.law.tau.ac.il/ Heb/?CategoryID=499\&ArticleID=723 (accessed 1 June 2012)

Ben-Eliezer, U.

1999 "Is civil society emerging in Israel? Major trends in Israel Historiography", Israel Sociology, 2: 51-97.

Breman, Y.

Forthcoming "The detention of asylum seekers", in T. Kritzman (Ed.), Refugees in Israel, Van Leer Institute, Jerusalem.

Campbell, J.

2011 "The enduring problem of statelessness in The Horn of Africa: How nation-states and western courts (re)define nationality", International Journal of Refugee Law, 23(4): 656-679.

Collyer, M.

2006 "States of insecurity: Consequences of Saharan Transit Migration”, Compass Working Paper 31, WP. 06-31. Oxford.

Dayan, M.

1955 "Israel's border and security problems", Foreign Affairs, 33(2): 250-267

De Hass, H.

2008 "The inconvenient realities of African migration to Europe", Third World Quarterly, 29(7): 13051322 
Gidron, B., and H. Katz

1998 "Defining the Nonprofit Sector: Israel", The John Hopkins Comparative Sector Project, Working Papers, http://ccss.jhu.edu/wp-content/uploads/downloads/2011/09/Israel_CNP_WP26_1998.pdf (accessed 1 June 2012)

Gidron, B., Hagai Katz, and M. Bar

2003 The Third Sector In Israel-Between a Welfare State to Civil Society, Hakibutz Hameuhad, Tel Aviv [Hebrew]

Gross, A.

2004 "The Constitution, reconciliation, and Transitional Justice: Lessons from South Africa and Israel", Stanford Journal of International Law, 40: 47-104

Hamood, S.

2006 "African Transit Migration through Libya to Europe: The human cost", Forced Migration Studies, American University, Cairo.

Herzog, B.

2009 "Between Nationalism and Humanitarianism: the glocal discourse on refugees", Nations and Nationalism, 2(15):185-205.

Hotline for Migrant Workers

2009 "A decade of activism for Migrants Rights: fact and figures”, Tel Aviv.

Hotline for Migrant Workers

n.d "Until our hearts are completely hardened. Asylum Procedures in Israel", Tel Aviv. (Unpublished).

Kemp, A.

2000 "Contesting the limits of political participation: Latinos and Black African Migrant workers in Israel”, Ethnic and Racial Studies, 1(23): 94-119.

Korczyn, O.

2011 "Where governmentality ends: Border control officers and deportation of sojourners in Israel", International Labor and Working Class History, 79: 81-102.

Kritzman-Amir, T.

2009 “'Otherness' as the underlying principle in Israel's asylum regime”, Israeli Law Review, 42: 602627.

Lustic, I.

1999 "Israel as a non-Arab state: The political implications of mass immigration of non-Jews", Middle East Journal, 55(3): 417-433.

Offer, S.

2004 "The socio-economic integration of the Ethiopian community into Israel", International Migration, 42(3): 29-54.

Paz, J.

2011 "'Ordered disorder: African asylum seekers in Israel and discursive challenges to an emerging refugee regime”, UNHCR Research Paper no. 205, March, Geneva. http://www.unhcr.org/4d7a26ba9.html (accessed 1 June 2012)

Perry, A.

2010 “Solving Israel's African refugee crisis", Virginia Journal of International Law, 51: 156-184.

Phillips, A.

2011 "A More Promised Land: Israel Copes With an Influx of Asylum Seekers by Implementing the 1951 Convention Relating the Status of Refugees and the 1967 Protocol”, American University Washington College of Law, January. http://works.bepress.com/aliyah_phillips/1/(accessed 1 June 2012)

Raijman, R.

2010 "Citizenship status, ethno-national origin and entitlement to rights: Majority attitudes toward minorities and immigrants in Israel", Journal of Ethnic and Migration Studies, 36(1): 87-106.

Richmond, N.

1993 "Israel's Law of Return: analysis of its evolution and present application", Dickinson Journal of International Law, 12: 95-133.

Sabar, G.

2010 "Israel and the Holyians: The Religio- Political discourse of Rights among African Migrant Laborers and African Asylum Seekers, 1999-2008", African Diaspora, 3: 43-76. 
Sabar, G., and A. Sharagei

2008 "Olumba Olumba in Israel: struggling on all fronts", African Identities, 3(6): 225-201.

Sassen, S.

2000 "Regulating immigration in a global age: A new policy landscape", Annals of the American Academy of Political and Social Science, 570: 65-77.

UNHCR.

1992 Handbook on Procedures and Criteria for Determining Refugee Status under the 1951 Convention and the 1967 Protocol relating to the Status of Refugees, UNHCR, Geneva.

UNHCR

2011 Eligibility Guidelines for Assessing the International Protection Needs of Asylum-Seekers from Eritrea. UNHCR, Geneva.

US Department of State

2011 Human Rights Report: Israel and the Occupied Territories, US Department of State, Washington D.C.

Yishay, Y.

2003 Civil Society in Israel, Carmel Publishers, Jerusalem. [Hebrew].

Yishay, Y.

2008 "Civil Society under Liquidation?", The Civil Society and Third Sector in Israel, 2(2): 27-28 [Hebrew] 